\title{
THE INFLUENCE OF COMPETITION IN THE GROWTH-CLIMATE RELATIONSHIP OF Pinus taeda: A CASE STUDY IN SOUTHERN BRAZIL
}

\author{
Cristine Tagliapietra Schons ${ }^{1 *}$, Emanuel Arnoni Costa² ${ }^{2}$ César Augusto Guimarães Finger ${ }^{3}$ \\ ${ }^{1}$ Universidade Federal de Santa Maria, UFSM, Programa de Pós-Graduação em Engenharia Florestal, Santa Maria, Rio Grande do Sul, Brasil \\ - cristschons@gmail.com* \\ ${ }^{2}$ Universidade Federal de Uberlândia, UFU, Instituto de Ciências Agrárias, Monte Carmelo, Minas Gerais, Brasil - \\ emanuelarnonicost@gmail.com \\ ${ }^{3}$ Universidade Federal de Santa Maria, UFSM, Departamento de Ciências Florestais, Santa Maria, Rio Grande do Sul, Brasil; Universidade \\ Tecnológica Federal do Paraná, UTFPR, Professor Visitante do Programa de Pós-Graduação em Agroecossistemas, Dois Vizinhos, Paraná, \\ Brasil - cesarfinger.ufsm@gmail.com
}

Recebido para publicação: 31/05/2018 - Aceito para publicação: 21/09/2018

\begin{abstract}
Resumo
Influência da competição na relação crescimento-clima de Pinus taeda: um estudo de caso no sul do Brasil. Entender como o clima afeta o crescimento das árvores é essencial para avaliar os impactos das mudanças climáticas nas florestas. Além disso, árvores em ambientes mais competitivos parecem responder ao clima de maneira diferente do que árvores em ambientes menos competitivos. Uma importante ferramenta para investigar as relações entre crescimento e ambiente é a datação dos anéis de crescimento. Este estudo teve como objetivo caracterizar os fatores climáticos que afetam o crescimento de Pinus taeda no sul do Brasil em dois tipos distintos de povoamentos: árvores de crescimento aberto e árvores sob competição. Nossa hipótese é que as árvores sob competição apresentam respostas mais vulneráveis à variabilidade climática do que as árvores de crescimento aberto. Foram usados trados de incremento para acessar o crescimento de longo prazo através dos anéis de crescimento. Correlação de Pearson foi aplicada para comparar o crescimento radial com dados climáticos mensais e anuais. As cronologias geradas para os dois ambientes apresentam padrões de crescimento similares ano a ano. No entanto, as árvores sob competição são mais sensíveis sob condições climáticas limitadas do que as árvores de crescimento aberto. A disponibilidade de água durante a atual primavera / verão foi a principal restrição climática para o crescimento de $P$. taeda na região, seguido por altas temperaturas durante o verão, provavelmente devido a restrições fotossintéticas. O artigo fornece informações adicionais sobre fatores climáticos que contribuem para modelos de crescimento e relata um importante campo de pesquisa, considerando o planejamento do manejo florestal no futuro.

Palavras-chave: Dendroclimatologia; sinais climáticos; dinâmica de crescimento; densidade de povoamento; subtrópicos
\end{abstract}

\begin{abstract}
Understanding how climate affects tree growth is crucial for assessing climate change impacts on forests Furthermore, trees in more competitive environments appear to respond to climate differently than trees in less competitive environments. An important tool for investigating the growth-environment relationships is tree ring dating. This study aimed to characterize the climatic factors that affect Pinus taeda growth in southern Brazil in two distinct stand types: open growth trees and competing trees. We hypothesized that competing trees present more vulnerable responses to climate variability than open growth trees. Thus, we used increment borers to access long-term growth through tree rings. Pearson's correlation was applied to compare radial growth with monthly and annual climatic data. The chronologies generated for the two environments present similar yearto-year growth patterns. However, competing trees are more sensitive under limiting climate conditions than open growth trees. Water availability during the current spring/summer was the primary climate constraint for $P$. taeda growth in the region, followed by high temperatures during the summer, probably due to photosynthetic restrictions. The paper provides additional information on climatic factors that contribute to growth models and reports an important research field, considering planning forest management in the future. Keywords: Dendroclimatology; climate signs; growth dynamics; stand density; subtropics
\end{abstract}

\section{INTRODUCTION}

Climate change is expected to affect greatly the functioning of forest ecosystems, especially through a greater frequency and intensity of drought and an increase in average air temperature over the next years (IPCC, 2014). Understanding how climate affects tree growth is crucial for assessing climate change impacts on forests, and also to help developing strategies aiming species management.

Local climate time series and general circulation patterns, such as the Southern Oscillation Index (SOI), may strongly affect the performance of forest populations. It is important to firmly establish the climate variability impact on species' behavior over time, in order to make better projections on how those species will respond under

FLORESTA, Curitiba, PR, v. 49, n. 3, p. 513 - 522, jul/set 2019

Schons, C. T. et.al.

ISSN eletrônico 1982-4688

DOI: $10.5380 /$ rf.v49 i3.59705 
a more variable scenario. However, growth and yield conventional statistical models have been based on dendrometric data of the stand, limiting the predictions of future growth by disregarding climatic variations (LU et al., 2015).

Competition among trees for resources also affects the growth rate of woody species, due to limited access to water, light, and nutrients (JOHNSON; SMITH, 2009), and so does the growth-climate relationship (MAZZA et al., 2014). Trees in more competitive environments appear to respond to climate differently than trees in less competitive environments (MORENO-GUTIÉRRES et al., 2012). Depending on stand structural attributes, a same type of forest community might exhibit different responses in the face of changing climatic conditions by increasing a tree's sensitivity to climate or modulating the adaptation capacity of forests to climatic stress (LINARES et al., 2010; MAZZA et al., 2014). These interactions between climate and competition are complex and their effects may vary by species, region, tree age, and tree size (JOHNSON et al., 2017), requiring further investigations.

An important tool for investigating the growth-environment relationships is tree ring dating. It presents information about the changes that have occurred over the centuries, through the responses expressed by the trees (FRITTS, 1976). Dendrochronological studies for the most diverse purposes have been prominent subjects in tropical and subtropical regions in recent years, due to confirmed annual ring formation in trees found in these sites (MATTOS et al., 2007; HARLEY et al., 2011; ANDREACCI et al., 2014).

Loblolly pine (Pinus taeda L.), native to the southeastern region of the United States, is an important timber species and it has been widely planted in tropical and subtropical regions around the world, such as in South Africa, New Zealand, Australia, and Brazil - predominantly in the southern region of the country. In this region, Pinus taeda has been one of the most planted species since the 1960s, due to its adaptability to climatic conditions, its diversity in use and rapid growth (BOGNOLA et al., 2008). Its wood is used for mechanical processing in the production of sawn pieces for structures, furniture making, packaging, frames, and panels of various types.

This study aimed to characterize the climatic factors that affect Pinus taeda L. growth in southern Brazil in two distinct stand types: open growth trees and competing trees. We hypothesized that competing trees present more vulnerable responses to climate in comparison to open growth trees.

\section{MATERIALS AND METHODS}

\section{Study area}

The study was conducted at Universidade Federal de Santa Maria (UFSM) campus, located in the Depressão Central region of state of Rio Grande do Sul (29 ${ }^{\circ} 43^{\prime} 12$ "S, $53^{\circ} 42^{\prime} 60^{\prime \prime}$ W; 95 m a.s.1.), city of Santa Maria, in a dense 50-year-old Pinus taeda plantation and in a nearby arboretum $(<0.5 \mathrm{~km})$ with scattered $P$. taeda trees. The plantation had an initial density of approximately 1110 trees $^{-1} \mathrm{a}^{-1}$. In sharp contrast, tree density in neighboring open growth stand is less than 30 trees ha ${ }^{-1}$, with a grassy understorey. According to Köppen's classification, the region's climate is humid subtropical (Cfa), characterized by hot summers and well distributed precipitation throughout the year, with an average of annual precipitation of $1720 \mathrm{~mm}$ (ALVARES et al., 2013). The average annual temperature is $19.1^{\circ} \mathrm{C}$, with average temperatures of $32.0^{\circ} \mathrm{C}$ and $9.0^{\circ} \mathrm{C}$ during the hot and cold months, respectively (HELDWEIN et al., 2009). The distribution of precipitation and temperatures throughout the year can be seen in Figure 1. The soil in the region is classified as Argissolo Vermelho distrófico and it is present in the sampling area generally in a condition of low natural fertility with a high degree of compaction (BRUN et al., 2012).

\section{Sample trees}

In May 2015, 10 trees were sampled in each stand type (20 trees in total). EPS values (expressed population signal, see next section) were used to assess whether the samples were representative for building a population chronology. Two cores per tree were sampled with an increment borer of $0.4 \mathrm{~cm}$ in diameter. The cores were collected at $1.30 \mathrm{~m}$ height and oriented at $90^{\circ}$ to each other, trying to avoid compression wood. Samples were air dried and sanded for later analyses of tree rings.

The open growth trees selection intended to analyze climatic signs of individuals at their maximum potential for growth and crown opening. Also, the sampling of older trees growing under competition allows us to explore long-term climate responses under more restrictive growth conditions.

Additional dendrometric information such as diameter at breast height (dbh), total height (h), crown insertion height (hic), and four measurements of crown radius (cr) were collected, which allowed us to calculate crown diameter $(\mathrm{cd}=2 * \mathrm{cr})$ and crown length $(\mathrm{cl}=\mathrm{h}-\mathrm{hic})$. 


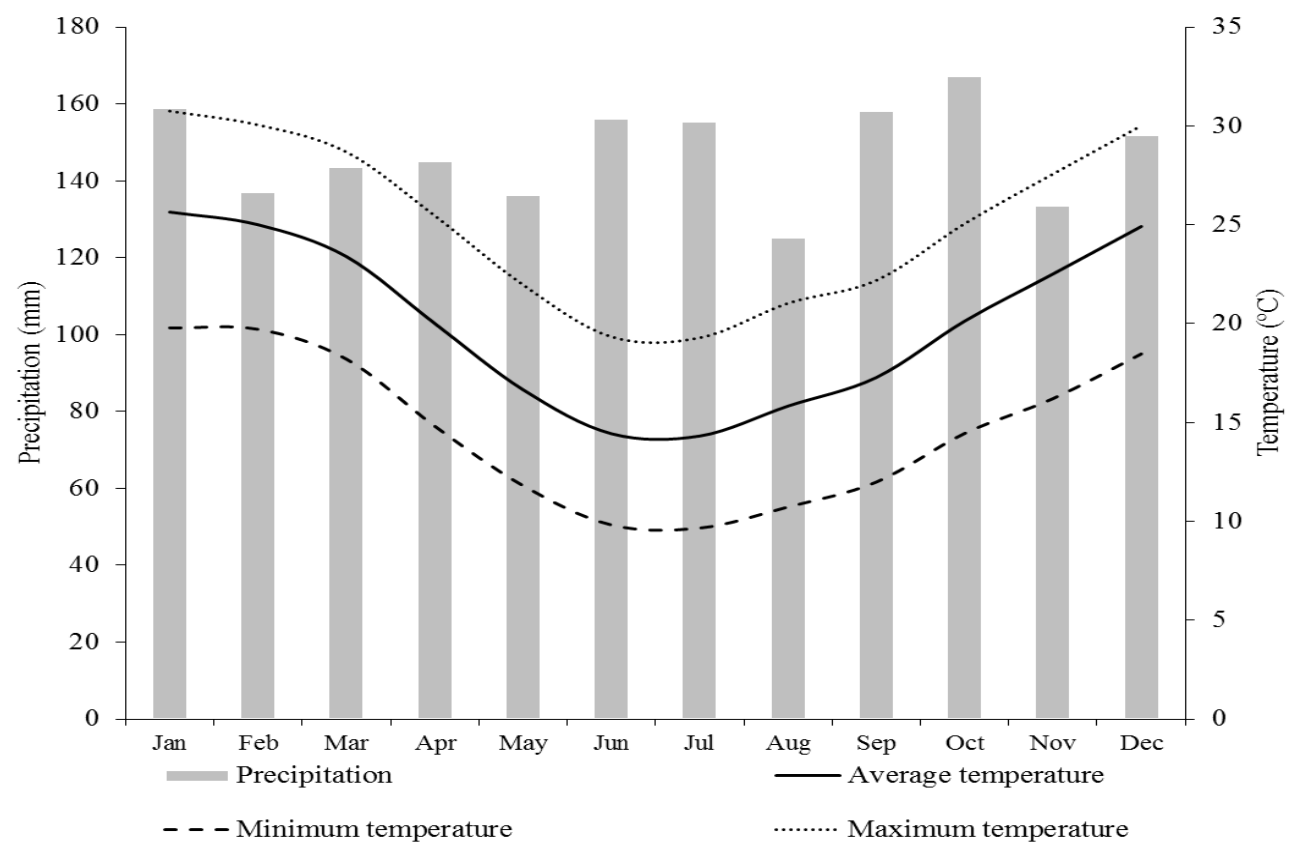

Figure 1. Monthly distribution of precipitation and minimum, average and maximum temperatures from 1968 to 2014.

Figura 1. Distribuição mensal de precipitação e temperaturas mínimas, médias e máximas entre 1968 e 2014.

\section{Obtaining the time series}

The first data examination was related to cross-dating, verifying the synchronization of the rings among the radius of the same tree and among trees by means of a graph. When synchronization problems were detected, the tree core was reexamined. COFECHA software (HOLMES, 1983) was used for verifying the statistical crossdating. Samples of open growth and competing trees were tested separately and grouped. The segments were analyzed every 20 years and overlapped every 10 years, seeking the critical limit for correlation of 0.5155 at $99 \%$ confidence level. In this step, COFECHA software tests each transformed series against the Master series (average), using correlation analyses along the length of the selected segment and overlapping.

After the correct dating, ARSTAN software (COOK; HOLMES, 1984) was used to standardize the ring widths. We used a conservative linear regression in order to preserve short-term and medium-term effects of climate and competition while smoothing out long-term effects from factors such as age (ring widths may decrease on larger trees due to the increased bole area that the ring must cover) (JOHNSON et al., 2017). From this, we created a standard ring width chronology for each environment and a general chronology comprising all trees.

The next parameter calculated within each stand type was EPS (WIGLEY et al., 1984), also analyzed every 20 years and overlapped every 10 years. EPS is a standard method in dendrochronology used to evaluate how well a chronology of $n$ tree-ring series represents the population's target signal. It is calculated by:

$$
\text { EPS: } \frac{n \bar{r}}{[1+(n-1) \bar{r}]}
$$

In which: $\mathrm{n}=$ number of tree-ring series used in the chronology construction; $\bar{r}=$ mean correlation between the series.

Values $>0.85$ indicate that the number of samples integrating the chronology is large enough to capture an adequate percentage of the theoretic signal present in an infinitely replicated chronology.

\section{Dendroclimatic analyses}

We cataloged precipitation data as well as minimum, average and maximum temperatures from 1968 to 2014 from the meteorological station of the Instituto Nacional de Meteorologia (INMET), located on the campus of UFSM. The meteorological station is approximately $1 \mathrm{~km}$ (straight line) from the data collection site. We calculated potential monthly evapotranspiration (PET) by the Thornthwaite method (1948) and we used the following equation to calculate aridity index (AI):

$$
A I=100 *\left(\frac{P}{P E T}\right)
$$

FLORESTA, Curitiba, PR, v. 49, n. 3, p. 513 - 522, jul/set 2019.

Schons, C. T. et.al.

ISSN eletrônico 1982-4688 
In which: $\mathrm{PET}=$ Potential monthly evapotranspiration $(\mathrm{mm})) ; \mathrm{P}=$ monthly precipitation $(\mathrm{mm})$.

Southern Oscillation Index (SOI) data (available at http://www.cpc.ncep.noaa.gov/data/indices/soi) is calculated as the normalized difference of the Sea Level Pressure between Tahiti Island in the central Pacific and Darwin, Australia (CATTANEO et al., 2013). Negative values are related to El Niño events and positive values to La Niña events.

Pearson correlation coefficients were calculated to test the relationships between the index of the chronologies and the mean values of the climatic variables generated for annual and monthly intervals. The significance of these growth-climate correlations was verified at 5\% probability, which allowed for inferences regarding the influence of climatic factors on the formation of tree rings.

The period from July to June was considered the growth year for the species in the region. We considered 18 months to test the influence of each monthly climatic variable on annual growth, covering the climate of the growth year (current) and 6 months of the previous year. This is justified because the previous conditions may affect the amount of carbon fixed and allocated for tree growth (FOSTER; BROOKS, 2001). Thus, the monthly values were paired with the growth indexes yearly for the correlations of the current year. In addition, the series was moved in one year to test the influence of the previous year.

\section{RESULTS}

Dbh varied between 40.1 and $98.0 \mathrm{~cm}$ for open growth trees and between 41.0 and 69.4 for competing trees. Height varied from 15.7 to $35.5 \mathrm{~cm}$ for open growth trees and from 26.4 to 34.5 for competing trees, creating distinct structures between the environments (Table 1).

Table 1. Descriptive statistics of dendrometric variables of Pinus taeda sampled in this study. Tabela 1. Estatística descritiva das variáveis dendrométricas de Pinus taeda amostradas neste estudo.

\begin{tabular}{lcccc}
\hline Condition & Variable & Average & $\begin{array}{c}\text { Standard } \\
\text { deviation }\end{array}$ & $\begin{array}{c}\text { Variation } \\
\text { coefficient (\%) }\end{array}$ \\
\hline \multirow{3}{*}{ Open growth } & $\mathrm{dbh}$ & 64.2 & 17.5 & 27.2 \\
& $\mathrm{~h}$ & 20.7 & 5.3 & 25.6 \\
& $\mathrm{hic}$ & 4.6 & 2.1 & 45.3 \\
& $\mathrm{~cd}$ & 12.3 & 2.4 & 19.9 \\
In competition & $\mathrm{cl}$ & 16.2 & 3.5 & 21.5 \\
& $\mathrm{dbh}$ & 49.0 & 8.5 & 17.3 \\
& $\mathrm{~h}$ & 31.2 & 2.3 & 7.4 \\
& $\mathrm{hic}$ & 24.1 & 1.4 & 6.0 \\
& $\mathrm{~cd}$ & 6.5 & 0.6 & 9.5 \\
& $\mathrm{cl}$ & 7.1 & 1.7 & 24.1 \\
\hline
\end{tabular}

$\mathrm{dbh}=$ diameter at $1.3 \mathrm{~m}$ (in $\mathrm{cm}) ; \mathrm{h}=$ total height (in $\mathrm{m})$; hic = crown insertion height (in $\mathrm{m}) ; \mathrm{cd}=$ crown diameter (in $\mathrm{m}$ ); $\mathrm{cl}=\mathrm{crown}$ length (in $\mathrm{m})$.

The 20 dated series from open growth trees produced a 39-year chronology (1975-2014) with a high interseries correlation (0.603) and mean sensitivity (0.270) and the 20 dated series from competing trees produced a 49-year chronology (1965-2014), also with a high intercorrelation (0.600) and mean sensitivity (0.292). No series had to be discarded. High EPS values $(>0.85)$ in both types of stands indicate that constructed chronologies from detrended individual series were representative of radial growth variations of the whole population of trees (WIGLEY et al., 1984) (Table 2).

Table 2. Dendrochronological characteristics of Pinus taeda chronologies.

Tabela 2. Características dendrocronológicas das cronologias de Pinus taeda.

\begin{tabular}{lccc}
\hline Description & Open growth & $\begin{array}{c}\text { Condition } \\
\text { In competition }\end{array}$ & General \\
\hline Number of trees & 10 & 10 & 20 \\
\hline Number of dated series $^{a}$ & 20 & 20 & 40 \\
\hline Master series range (years) $^{\text {Average mean sensitivity }}{ }^{b}$ & 39 & 49 & 49 \\
\hline Series intercorrelation $^{c}$ & 0.270 & 0.292 & 0.283 \\
\hline Mean EPS $^{d}$ & 0.603 & 0.600 & 0.556 \\
\hline
\end{tabular}

${ }^{a}$ The series are individual radius after cross-dating. ${ }^{b}$ Average mean sensitivity is a measure of the annual variability of ring width in the Master series. ${ }^{c}$ Series intercorrelation indicates the common signal strength. Critical limit for correlation was 0.5155 at $99 \%$ confidence. ${ }^{d}$ EPS, expressed population signal. 
Significant series intercorrelation (Table 2) and common signals among radial growth were identified (Figure 2a), showing the correct dating of the series. This enabled us to generate the Master series (average) for each stand types and the general Master series, which comprises all the trees (Figure 2b) and whose synchronization was also significant. In general, the chronologies exhibited highly similar year-to-year growth pattern, with variation only in the amplitudes of growth, maintaining common signs in the rings.
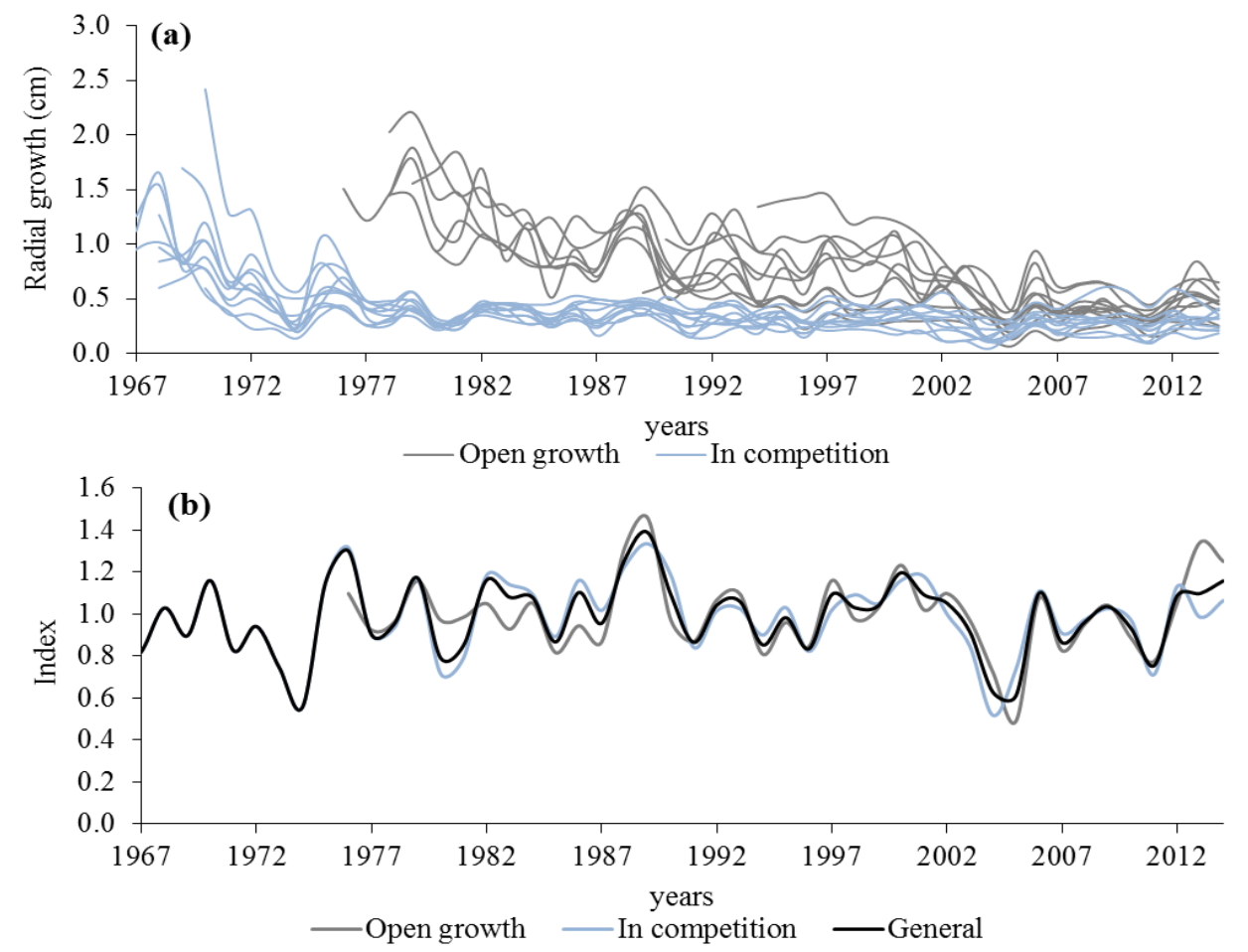

Figure 2. (a) Actual radial growth of the trees selected for the construction of the chronology; (b) Standardized Master series for general conditions, in competition and open growth trees of Pinus taeda.

Figura 2. (a) Incremento real das árvores selecionadas para a construção da cronologia; (b) Série Master padronizada para condições gerais, sob competição e árvores de crescimento aberto de Pinus taeda.

The established growth-climate correlations were based on records of 39 years for the open growth trees and 47 years for the competing trees (according to the period in which the tree ring chronology and climatic registers overlap).

For the open growth trees, the correlation between growth and the annual values of the climatic variables was significant $(\mathrm{p}<0.05)$ only for precipitation $(\sigma=0.3742 ; \mathrm{p}=0.0187)$. For the competing trees, we found significant correlation for precipitation $(\sigma=0.4687$; $\mathrm{p}=0.0009)$, AI $(\sigma=0.4237$ and $\mathrm{p}=0.0029)$ and maximum temperature $(\sigma=-0.3389$ and $\mathrm{p}=0.0196)$ (Table 3).

Table 3. Pearson's correlation coefficients (r) and P-values (in parentheses) of the relationship between annual climatic variables and Pinus taeda chronologies. Chronologies from each stand type as well as the averaged chronology across stand types are considered.

Tabela 3. Coeficientes de correlação de Pearson (r) e P-valores (entre parênteses) da relação entre as variáveis climáticas anuais e as cronologias de Pinus taeda. Cronologias de cada tipo florestal, bem como a cronologia média entre os tipos florestais são consideradas.

\begin{tabular}{|c|c|c|c|c|c|c|c|}
\hline & Precipitation & $T \max$ & $T \min$ & T med & SOI & ETP & IA \\
\hline Open growth & $0.374(0.019)$ & $\begin{array}{l}-0.290 \\
(0.073)\end{array}$ & $\begin{array}{c}0.148 \\
(0.367)\end{array}$ & $\begin{array}{l}-0.140 \\
(0.395)\end{array}$ & $\begin{array}{c}-0.046 \\
(0.779)\end{array}$ & $\begin{array}{l}-0.079 \\
(0.633)\end{array}$ & $\begin{array}{c}0.254 \\
(0.119)\end{array}$ \\
\hline In competition & $0.469(0.001)$ & $\begin{array}{c}-0.339 \\
(0.020) \\
\end{array}$ & $\begin{array}{c}0.145 \\
(0.332) \\
\end{array}$ & $\begin{array}{c}-0.132 \\
(0.378) \\
\end{array}$ & $\begin{array}{l}-0.067 \\
(0.655)\end{array}$ & $\begin{array}{c}-0,037 \\
(0.807)\end{array}$ & $\begin{array}{c}0,424 \\
(0.003) \\
\end{array}$ \\
\hline General & $0,493(0.000)$ & $\begin{array}{c}-\mathbf{0 , 3 1 5} \\
(0.031)\end{array}$ & $\begin{array}{c}0,172 \\
(0.248) \\
\end{array}$ & $\begin{array}{c}-0,113 \\
(0.449) \\
\end{array}$ & $\begin{array}{c}-0,115 \\
(0.442) \\
\end{array}$ & $\begin{array}{c}-0,029 \\
(0.846)\end{array}$ & $\begin{array}{c}0,407 \\
(0.004) \\
\end{array}$ \\
\hline
\end{tabular}

Significant values $(\mathrm{P}<0.05)$ are highlighted in bold.

FLORESTA, Curitiba, PR, v. 49, n. 3, p. 513 - 522, jul/set 2019

Schons, C. T. et.al.

ISSN eletrônico 1982-4688

DOI: $10.5380 /$ rf.v49 i3.59705 
Figure 3 shows the analysis of the climatic influence of each month on the annual growth of the species, considering the values obtained in the months of the current year and the previous year.

For monthly precipitation, we found a positive correlation between growth and, especially, the months of September, November, March and April of the current year, which is the representative growth season for the radial growth of the species over the years. Minimum temperatures showed strong positive correlation during the growing season, similar to that found for precipitation. Conversely, prior to the growing season, minimum temperatures showed a negative correlation pattern from January to June. Maximum temperatures tended to correlate negatively in practically the whole study period.

Average temperature and evapotranspiration exhibited low correlation with growth. SOI, which expresses general circulation patterns (unlike previous regional variables), also presented low correlation with growth.

There were significant differences in climate-growth relationships between the environments (Figure 3 a,b) and sometimes the competing trees exhibited earlier and stronger responses.

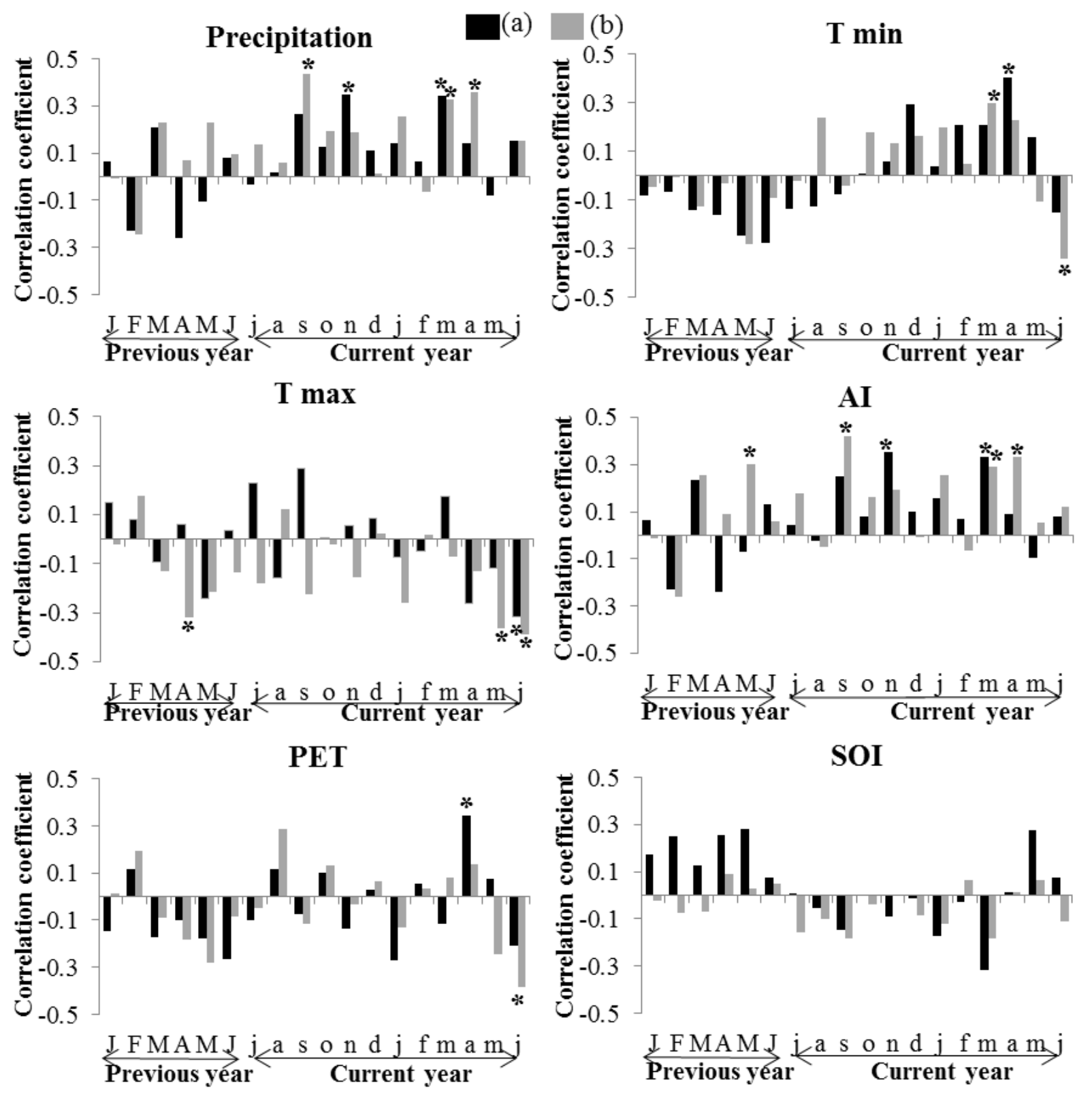


Figure 3. Correlations between the ring width index and monthly climate variables (total precipitation, minimum temperature (T min), maximum temperature (T max), Aridity Index (AI), Evapotranspiration (PET) and Southern Oscillation Index (SOI)) from the previous January to the current June. (a) open growth trees; (b) competing trees. The critical value of the correlation $(\mathrm{p}<0.05)$ is 0.317 for open growth and 0.288 for competing trees.

Figura 3. Correlações entre o índice de largura do anel e as variáveis climáticas mensais (precipitação total, temperatura mínima ( $\mathrm{T}$ min), temperatura máxima ( T max), Índice de Aridez AI), Evapotranspiração (PET) e Índice de Oscilação Sul (SOI)) do mês de janeiro anterior até o mês de junho atual. (A): árvores de crescimento aberto; (B): árvores sob competição. O valor crítico da correlação (p <0,05) é 0,317 para árvores de crescimento aberto e 0,288 para concorrentes.

\section{DISCUSSION}

When analyzed for shorter periods of time, climatic variables are able to better characterize growth, showing higher correlations. Defining the influence factors as well as the periods in which they are most influential is useful for inclusion in growth models aimed at more accurate predictions by adding environmental variables.

Water availability during the growing season was found as the primary climate constraint for the Pinus taeda growth in the region. Samuelson et al. (2013) studying this species along a natural distribution (Mississippi-North Carolina) and in a more favorable exotic environment (Hawaii) also found that increases in drought frequency and intensity may impact Loblolly Pine growth, even at moderate temperatures, when the demand for evaporation is low. Similar relationships were described for Pinus elliotti by Harley et al. (2011) in southern Florida, defining the precipitation and humidity available during the growing season as the main driver of annual growth of the species. The site soil may have somewhat influenced this result by making plants more sensitive to this response, unlike what would happen in soil with good structure and fertility. Nevertheless, it is clear that there is a positive/negative growth pulse caused by the increase/decrease in precipitation, regardless of the amplitude.

Furthermore, inter-tree competition for water can make trees growing under higher densities (Figure 3b) more vulnerable to drought conditions than trees growing in lower densities (Figure 3a) (MAZZA et al., 2014). This may be associated to the net under-canopy precipitation, which is always found to be greater in an open stand than in a high-density stand, because of the greater interception by the tree canopy (MAZZA et al., 2011). The larger year-to-year variability of tree rings width in competing trees (higher Mean sensitivity; Table 2) reinforces the fact that these trees may rely more heavily on current year rainfall than open growth trees. Moreno-Gutiérrez et al. (2012) find some noteworthy differences that suggest that Pines (Pinus halepensis) in dense competition are more prone to water shortage than Pines in open growth stands.

In addition, the species appears to respond negatively under higher temperatures, especially competing trees. Temperature directly affects photosynthesis and it influences plant metabolic processes and the effectiveness of various enzymes. For Pinus taeda, the great photosynthetic efficiency occurs between 20 and $26^{\circ} \mathrm{C}$ (WERTIN et al., 2012). Moreover, according to Wertin et al. (2012), the ratio between photosynthesis and respiration of Pinus taeda declines linearly from 15 to $35^{\circ} \mathrm{C}$. This indicates a lower net carbon gain at higher temperatures. Therefore, it supports the negative growth-maximum temperature correlation found, even in the autumn and winter months. Moderate temperatures throughout the year most likely contribute to increased growth. Oliveira et al. (2010) also identified a relationship between high temperatures and water stress in southern Brazilian highlands for Araucaria angustifolia. A higher stomatal conductance in open growth stands (MORENO-GUTIÉRREZ et al., 2012), possibly influenced by the distinct structure of the crown (Table 1) (higher crown volume and light access of open growth trees), may also suggest a better performance of these stands, making them less susceptible to temperature increasing and changes in water availability.

As regards the relationship between the precipitation of the previous year and growth, Höll (1985) describes that this correlation (when confirmed) indicates an influence of water supply on the formation of nutrient reserves, which in turn are mobilized at the beginning of the next growth period. This correlation was not clearly visualized in this study. However, the relationships of growth and minimum temperature, which were negative in months prior to the growing season and positive during the current months (of the growing season of the year), suggest that the temperature determines if the species mobilizes carbohydrates for wood formation at the end of the season or stores them for the next growth period. Oliveira et al. (2010)

FLORESTA, Curitiba, PR, v. 49, n. 3, p. 513 - 522, jul/set 2019.

Schons, C. T. et.al.

ISSN eletrônico 1982-4688

DOI: $10.5380 /$ rf.v49 i3.59705 
argue that higher temperatures in autumn result in a lower level of stored carbohydrates available for the next growing season, causing the narrowing of the new growth ring, and the opposite is expected under low temperatures.

Aridity Index (AI), which expresses the relationship between available moisture by precipitation and the capacity to compensate potential water demand, is another important variable in simulating past climatic data (GHOLAMI et al., 2017). In this study, although AI presented a correlation pattern similar to precipitation, we found that in certain months it better described the annual growth pulses, both positive and negative.

\section{CONCLUSION}

- The statistically significant chronologies constructed for the two environmental conditions confirm the potential of Pinus taeda for dendroclimatic studies in subtropical regions.

- The growth pattern between chronologies exhibited highly similar year-to-year variation. However, competing trees were found to be more vulnerable to climate variability in comparison to open growth trees.

- Water availability during the current spring/summer is the most important factor in determining radial growth of Pinus taeda in the region, followed by high temperatures during the summer, probably due to photosynthetic restrictions.

- Our results indicate that the influence of climatic variability and stand structure on the tree growth should be taken into account when considering forest management planning in the future, in order to foster long-term sustainability.

\section{ACKNOWLEDGEMENTS}

We would like to thank Evandro Zanini Righi (in memoriam) for all the support, encouragement, and contributions during this process. We would also thank Lorenna Eleamen, Victor Neto, and Cyro Favalessa for the assistance with field data collection, sample preparation, and laboratory work.

\section{REFERENCES}

ALVARES, C. A.; STAPE, J. L.; SENTELHAS, P. C.; DE MORAES, G.; LEONARDO, J.; SPAROVEK, G. Köppen's climate classification map for Brazil. Meteorologische Zeitschrift, v. 22, n. 6, p. 711-728, 2013.

ANDREACCI, F.; BOTOSSO, P.C.; GALVÃO, F. Sinais climáticos em anéis de crescimento de Cedrela fissilis em diferentes tipologias de Florestas Ombrófilas do Sul do Brasil. Floresta, Curitiba, v. 44, n. 2, p. 323-332, 2014.

BOGNOLA, I. A.; RIBEIRO-JÚNIOR, P. J.; SILVA, E. A. A.; LINGNAL, C.; HIGA, A. R. Modelagem uni e bivariada da variabilidade espacial de rendimento de Pinus taeda L. Floresta, Curitiba, v. 38, n. 2, 2008.

BRUN, E. J.; ROSA, S. F.; ROPPA, C.; SCHUMACHER, M. V.; BRUN, F. G. K. Avaliação nutricional de espécies nativas utilizadas na arborização do campus da Universidade Federal de Santa Maria-RS. Revista da Sociedade Brasileira de Arborização Urbana, Piracicaba, v. 7, n. 1, p. 89-111, 2012.

CATTANEO, N.; PAHR, N.; FASSOLA, H.; LEPORATI, J.; BOGINO, S. Sex-related, growth-climate association of Araucaria angustifolia in the neotropical ombrophilous woodlands of Argentina. Dendrochronologia, Verona, v. 3, p. 147-152, 2013.

COOK, E. R.; HOLMES, R. L. Program ARSTAN user's manual. Tucson: The University of Arizona Press, $1984,15 \mathrm{p}$.

FOSTER, T. E.; BROOKS, J. R. Long-term trends in growth of Pinus palustris and Pinus elliottii along a hydrological gradient in central Florida. Canadian Journal of Forest Research, Ottawa, v. 31, p. 1661-1670, 2001.

FRITTS, H. C. Tree rings and climate. London: Academic Press, 1976, 567 p.

GHOLAMI, V.; JOLANDAN, M. A.; TORKAMAN, J. Evaluation of climate change in northern Iran during the last four centuries by using dendroclimatology. Natural Hazards, Dordrecht, v. 85, p. 1835-1850, 2017.

HARLEY, G. L.; GRISSINO-MAYER, H. D.; HORN, S. P. The Dendrochronology of Pinus elliottii in the Lower Florida Keys: Chronology Development and Climate Response. Tree-Ring Research, Tucson, v. 67, n. 1, p. 3950, 2011. 
HELDWEIN, A. B.; BURIOL, G. A.; STRECK, N. A. O clima de Santa Maria. Ciência e Ambiente, Santa Maria, v. 38, p. 43-58, 2009.

HÖLL, W. Seasonal fluctuation of reserve materials in the trunk wood of spruce (Picea abies (L.) Karst.). Journal of Plant Physiology, Stuttgart, v. 117, p. 355-362, 1985.

HOLMES, R. L. Computer-assisted quality control in tree-ring dating and measurement. Tree-Ring Bulletin, Tucson, v. 43, p. 69-75, 1983.

IPCC. IPCC Fifth Assessment Report. 2014. Available on: <http://www.ipcc.ch/report/ar5/index.shtml〉.

JOHNSON, C.; CHHIN, S.; ZHANG, J. Effects of climate on competitive dynamics in mixed conifer forests of the Sierra Nevada. Forest Ecology and Management, Amsterdam v. 394, p. 1-12, 2017.

JOHNSON, J. E.; SMITH, D. W. Principles of Regeneration Silviculture in Virginia. Virginia Cooperative Extension, 2009, 20 p.

LINARES, J. C.; CAMARERO, J. J.; CARREIRA, J. A. Competition modulates the adaptation capacity of forests to climatic stress: insights from recent growth decline and death in relict stands of the Mediterranean fir Abies pinsap. Journal of Ecology, Oxford v. 98, p. 592-603, 2010.

LU, Y.; COOPS, N. C.; WANG, T.; WANG, G. A. Process-based approach to estimate Chinese Fir (Cunninghamia lanceolata) distribution and productivity in southern China under climate change. Forests, Basileia, v. 6, n. 3, p. 360-379, 2015.

MATTOS, P. P.; SANTOS, A. T.; OLIVEIRA, Y. M.; ROSOT, M. A. Dendrocronologia de espécies da Floresta Ombrófila Mista do Município de Candói, PR. Pesquisa Florestal Brasileira, Colombo, v. 54, p. 153-156, 2007.

MAZZA, G.; AMORINI, E.; CUTINI, A.; MANETTI, M.C. The influence of thinning on rainfall interception by Pinus pinea L. in Mediterranean coastal stands (Castel Fusano-Rome). Annals of Forest Science, Les Ulis, v. 68, p. 1323-1332, 2011.

MAZZA, G.; CUTINI, A.; MANETTI, M.C. Influence of tree density on climate-growth relationships in a Pinus pinaster Ait. forest in the northern mountains of Sardinia (Italy). iForest, Viterbo, v. 8, p. 456-463, 2014.

MORENO-GUTIÉRREZ, C.; BATTIPAGLIA, G.; CHERUBINI, P.; SAURER, M.; NiCOLÁS, E.; CONTRERAS, S.; QUEREJETA, J.I. Stand structure modulates the long-term vulnerability of Pinus halepensis to climatic drought in a semiarid Mediterranean ecosystem. Plant, Cell and Environment, Oxford, v. 35, p. 10261039, 2012.

OLIVEIRA, M. J.; ROIG, F. A.; PILLAR, V. D. Climatic signals in tree-rings of Araucaria angustifolia in the southern Brazilian highlands. Austral Ecology, Windsor, v. 35, p. 134-147, 2010.

SAMUELSON, L. J.; EBERHARDT, T. L.; BARTKOWIAK, S. M.; JOHNSEN, K. H. Relationships between climate, radial growth and wood properties of mature loblolly pine in Hawaii and a northern and southern site in the southeastern United States. Forest Ecology and Management, Amsterdam, v. 310, p. 786-795, 2013.

WERTIN, T. M.; MCGUIRE, M. A.; IERSEL, M.; RUTER, J.M.; TESKEY, R. O. Effects of elevated temperature and [CO2] on photosynthesis, dark respiration, and biomass accumulation of Pinus taeda seedlings at a cool and a warm site within the species' current range. Canadian Journal of Forest Reserch, Ottawa, v. 42, p. 943-95, 2012.

WIGLEY, T. M. L.; BRIFFA, K. R.; JONES, P. D. On the average value of correlated time series with applications in dendroclimatology and hydrometeorology. Journal of Climate and Applied Meteorology, Washington, v. 23, p. 201-213, 1984.

FLORESTA, Curitiba, PR, v. 49, n. 3, p. 513 - 522, jul/set 2019.

Schons, C. T. et.al.

ISSN eletrônico 1982-4688

DOI: $10.5380 /$ rf.v49 i3.59705 
